\title{
Lehmann lovegrass in southeastern Arizona: Biomass pro- duction and disappearance
}

\author{
JERRY R. COX, G.B. RUYLE, AND B.A. ROUNDY
}

\section{Abstract}

Lehmann lovegrass (Eragrostis lehmanniana Nees), a perennial bunchgrass from southern Africa, has recently replaced native grasses on 200,000 ha in southeastern Arizona. Hence the need to determine annual fuctuations in live and dead biomass in wet and dry years. This information is necessary if we wish to determine (1) potential plant productivity changes on Arizona rangelands after the Lehmann lovegrass invasion, and (2) how the presence of Lehmann lovegrass has affected animal utilization and grazing management. Live biomass was present throughout the year but August peaks were almost $2,000 \mathrm{~kg} / \mathrm{ha}$ in 1 wet summer, 1,430 $\mathrm{kg} / \mathrm{ha}$ in 2 normal summers, and $960 \mathrm{~kg} / \mathrm{ha}$ in $1 \mathrm{dry}$ summer. Recent-dead approached zero in August when live peaked, and slowly accumulated in fall and winter. Old-dead peaked before the summer rains when temperature peaked and rapidly disappeared following snow accumulations in winter. Litter was highly variable among sampling areas, plots, and sampling dates but amounts usually peaked before the summer rains and decreased in winter and spring. Lehmann lovegrass annually produces 3 to 4 times more green forage than native grasses, but cattle prefer native grasses more than Lehmann lovegrass.

Key Words: Eragrostis lehmanniana, introduced perennial grass, live biomass, dead standing biomass, litter, above-ground productivity, Sonoran Desert, North America

When southwestern railroads were completed and the dangers from Indian raids reduced, large cattle and sheep herds were stocked on southeastern Arizona rangelands (Griffith 1901, Humphrey 1958). Between 1890 and 1930 , wet periods with abundant forage were followed by overstocking, and drought periods were followed by livestock reductions (Wagner 1952). With each successive cycle, perennial grass productivity declined and grasslands supported fewer livestock (Bryan 1925). Excessive and continuous grazing slowed grass recovery and favored shrub invasion, and the

\footnotetext{
Authors are range scientist, USDA, Agricultural Research Service, Aridland Watershed Research Unit, 2000 E. Allen Road, Tucson, Arizona 85719; and range management specialist and assistant professor, respectively. School of Natural Resources, University of Arizona, Tucson 85721. This paper reports on work supported by USDA, Agricultural Research Service and is a cooperative investigation with the University of Arizona.

Appreciation is extended to $\mathrm{S}$. Anderson and L. Yohnka for manuscript preparation; R.M. Madrigal, M.H. Martin-R., J.M. Ruyle, and M. Giner-M. for field assistance; Drs. S.C. Martin, H.L. Morton, and T.N. Johnson, Jr., for technical assistance; Bill Kruse at the Santa Rita Experimental Range for his cooperation; and USDA, Forest Service, Rocky Mountain Forest and Range Experiment Station for permission to use their land.

Accepted 21 December 1989.
}

semidesert grasslands become semidesert shrublands (Cooke and Reeves 1976).

Attempts to restore grassland productivity with native perennial grasses began in 1890 but most plantings failed because native grass seedlings could not compete with shrubs and introduced annuals for moisture and nutrients (Upson and McGinnies 1939). In the 1930s, seed collected from African perennial grasses were sown and evaluated for establishment and persistence. From hundreds of screening trials, a Lehmann lovegrass (Eragrostis lehmanniana Nees) accession was selected that matured quickly and produced abundant seed (Crider 1945). Between 1940 and 1980 land managers in Arizona established the species on 70,000 ha and the plant spread by seed to an additional 130,000 ha (Cox and Ruyle 1986).

The animal-carrying capacity of rangeland is dependent on the amount of plant biomass available to be converted to animal biomass. We believe that carrying capacity of Arizona rangelands increased after the Lehmann lovegrass invasion, but production potential of Lehmann lovegrass needs to be measured in wet and dry years to determine if this hypothesis is true. The first step in a program to evaluate carrying capacity should be to quantify the annual accumulation and decomposition characteristics of live biomass, dead standing biomass, and litter in Lehmann lovegrass grassland communities. This paper reports on studies in which the above-ground live biomass, recent-dead standing biomass, oldstanding biomass, and litter were examined over 3.5 years. The relative differences in yield accumulation and disappearance in response to climate were also studied.

\section{Methods and Materials}

The study site is located $40 \mathrm{~km}$ south of Tucson in southeastern Arizona $\left(31^{\circ} 41^{\prime} \mathrm{N}\right.$. lat., $100^{\circ} 37^{\prime} \mathrm{W}$. long.) on the Santa Rita Experimental Range. Elevation is $1,075 \mathrm{~m}$, slope is $2-5 \%$, and soil is a Comoro sandy loam (thermic Typic Torrifluvent). Soils are recent alluvium, weathered from granitic rocks, moderately acid $(\mathbf{p H}=$ 6.2-6.9); depths range from 0.2 to $2.5 \mathrm{~m}$ (Hendricks 1985). Average annual precipitation is $450 \mathrm{~mm}$, and it has varied from 175 to 700 $\mathrm{mm}$ in the past 80 years (Green and Martin 1967, Sellers and Hill 1974, Climatography of the United States (Arizona) 1982). Precipitation is bimodally distributed: approximately $60 \%$ comes as rain between July and September, and about $40 \%$ comes as rain or snow between October and April. May, June, and September are 


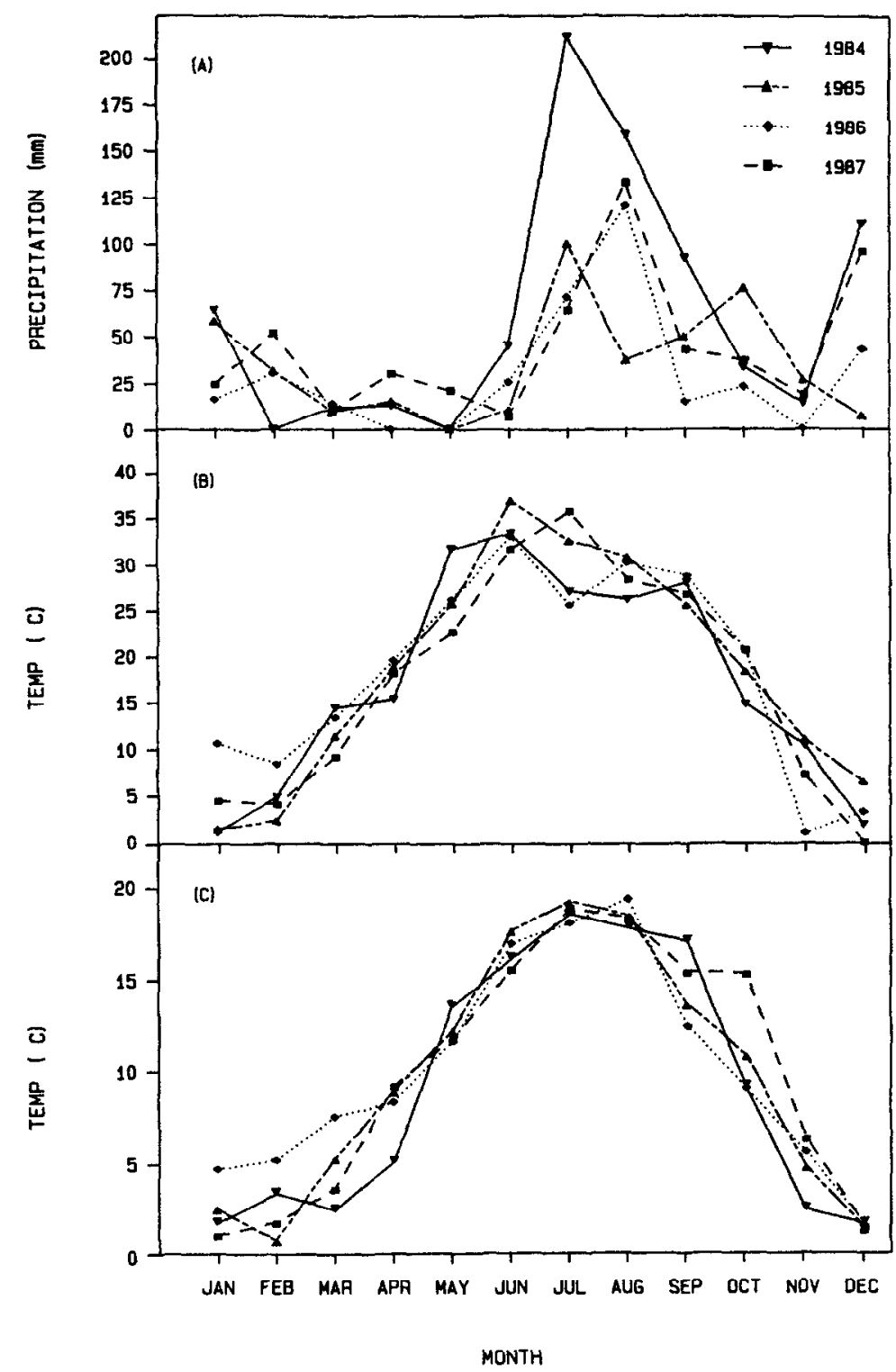

Fig. 1. Monthly precipitation (A), mean daytime maximums (B) and mean nighttime minimums (C) during 4 years at a Lehmann lovegrass site in southeastern Arizona.

usually dry but exceptions occur (Fig. 1-A). Daytime temperatures average $30^{\circ} \mathrm{C}$ in summer and nighttime temperatures average $5^{\circ} \mathrm{C}$ in winter, but daytime maximums frequently exceed $38^{\circ} \mathrm{C}$ in June and nighttime minimums are below $0^{\circ} \mathrm{C}$ in January and February (Figs. 1-B and 1-C).

\section{Experimental Design}

A 6-ha stand of dense, shrub-free Lehmann lovegrass was fenced to exclude livestock. Twelve, $15-$ by $15-\mathrm{m}$ plots were established in January 1984 and there were 4 plots in each of 3 blocks. One plot in each block was randomly selected for sampling at 2-week intervals between 14 March 1984 and 26 January 1985. Three additional plots were sampled between 14 March 1985 and 26 January 1986, and 3 more plots were sampled between 14 March 1986 and 26 January 1987. The remaining 3 plots were sampled between 14 March 1987 and 29 August 1987. Experimental design was a randomized complete block with 3 replications each year and sampling over 3.5 years.

\section{Biomass Sampling and Phenology}

On every sampling date, 10 previously unsampled 0.25 - by 0.25 $m$ quadrats were selected at random in each plot. Lehmann love- grass plants were clipped at the soil surface and litter collected from the soil surface. Tiller elongation and leaf development were monitored on 3 unclipped plants in each plot.

Forage from 3 of the 10 quadrats in a plot were separated into live (green), recent-dead standing (yellow) and old-dead standing (gray) components. Separated and unseparated forage samples and litter were dried in a forced-draft oven at $40^{\circ} \mathrm{C}$ for $72 \mathrm{~h}$ and weighed. Forage component dry weights from the 3 quadrats were pooled and the contribution of each to the total forage dry weight expressed as a percentage. Average component percentages were multiplied by total forage dry weight of unseparated quadrats. The derived dry weight component value for the 7 unseparated and the 3 separated quadrats were averaged to provide an estimate of plot biomass for each forage component.

\section{Climatic Data}

Precipitation and surface soil temperatures (Fig. 1) were measured daily with a CR-10 Campbell Scientific Weather Station'1. Daily precipitation was accumulated for all dates between harvests

'Mention of a commercial product is for the readers' convenience and does not imply endorsement by the USDA-Agricultural Research Service or the University of Arizona. 


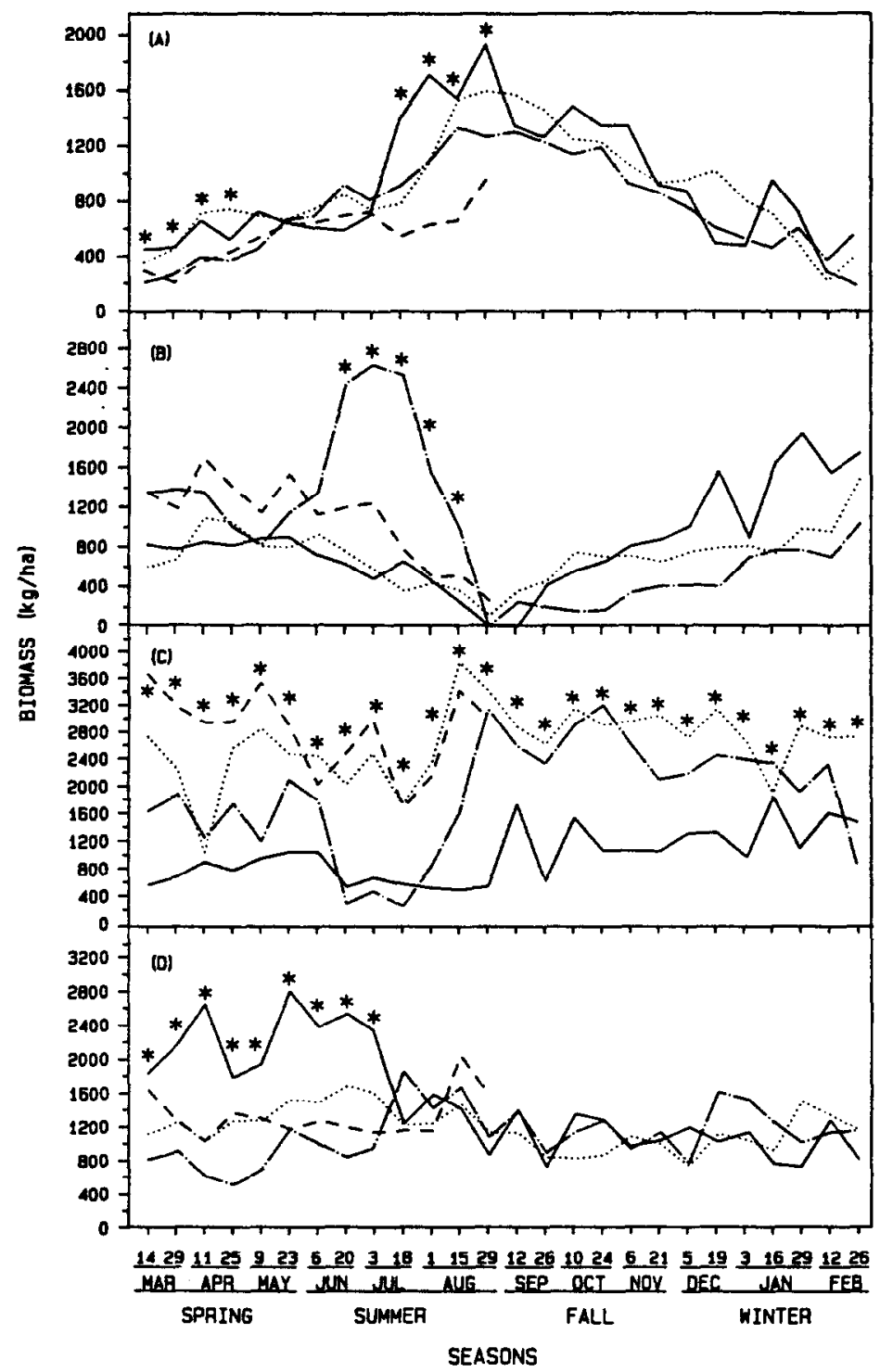

Fig. 2. Quantities of live (A), recent-dead standing (B), old-dead standing (C) and litter (D) of Lehmann lovegrass sampled over 3.5 years in southeastern Arizona. An asterisk $\left(^{(}\right)$indicates a significant difference $(P \leq 0.05)$ among years at the same sampling date. Sampling years were from $14 \mathrm{March} 1984$ -

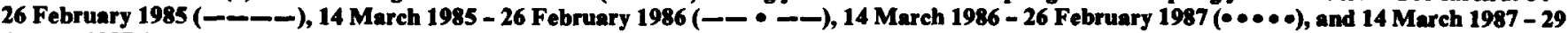
August 1987 (-- - $)$.

but individual storm amounts are presented when rapid growth occurs in summer.

\section{Statistical Analysis}

The year effect was evaluated for each forage component at each sampling date using analysis of variance. When F-values were significant ( $P \leq 0.05$ ), Least Significant Difference tests (Steel and Torrie 1960) were used to separate means.

In each of the years, a specific forage component would either accumulate or disappear in the same season. When this situations occurred regression analysis was used to correlate biomass component with environmental parameters (Cable 1975).

\section{Results and Discussion}

\section{Live Biomass}

Live biomass was different ( $P \leq 0.05$ ) among years at 4 spring and 4 summer sampling dates and similar at the remaining dates over the 3.5 years (Fig. 2-A). Initially it was expected that more green growth would occur in spring (March-May) 1985 and spring 1987 because precipitation in winter (December-February) 1984-85 $(175 \mathrm{~mm})$ and winter $1986-87(100 \mathrm{~mm})$ was almost twice that recorded in winter $1983-84(55 \mathrm{~mm})$ and winter 198586 (46 $\mathrm{mm})$. The assumption that Lehmann lovegrass would grow more rapidly in spring following a wet winter was incorrect because low nighttime temperatures in February $1985\left(-10^{\circ} \mathrm{C}\right)$ and February 1987 $\left(-15^{\circ} \mathrm{C}\right)$ damaged newly forming tillers and reduced spring live biomass production.

Summer (June-August) precipitation (Fig. 3) was above the long-term average $(196 \mathrm{~mm})$ in $1984(360 \mathrm{~mm})$, about equal to the average in $1986(190 \mathrm{~mm})$ and $1987(180 \mathrm{~mm})$, and below average in 1985 (130 mm). Peak live biomass production (Fig. 2-A) was greatest in $1984(1,925 \mathrm{~kg} / \mathrm{ha})$, intermediate in $1985(1,265 \mathrm{~kg} / \mathrm{ha})$ and $1986(1,595 \mathrm{~kg} / \mathrm{ha})$, and least in $1987(960 \mathrm{~kg} / \mathrm{ha})$ but peak live biomass production was not always directly related to total summer precipitation.

In the final 14 days of July 1984, 1985, and 1986, temperatures never exceeded $34^{\circ} \mathrm{C}$ and surface soils were moist (unpublished data, USDA-ARS, Tucson, Ariz.). Under these conditions Lehmann lovegrass culms elongated before $20 \mathrm{July}$, leaves expanded and elongated before 1 August, and seedheads were present before 15 August, whereas, in late July 1987 temperatures exceeded $38^{\circ} \mathrm{C}$ for 10 days, ranged from 35 to $37^{\circ} \mathrm{C}$ for 4 days, and plants 


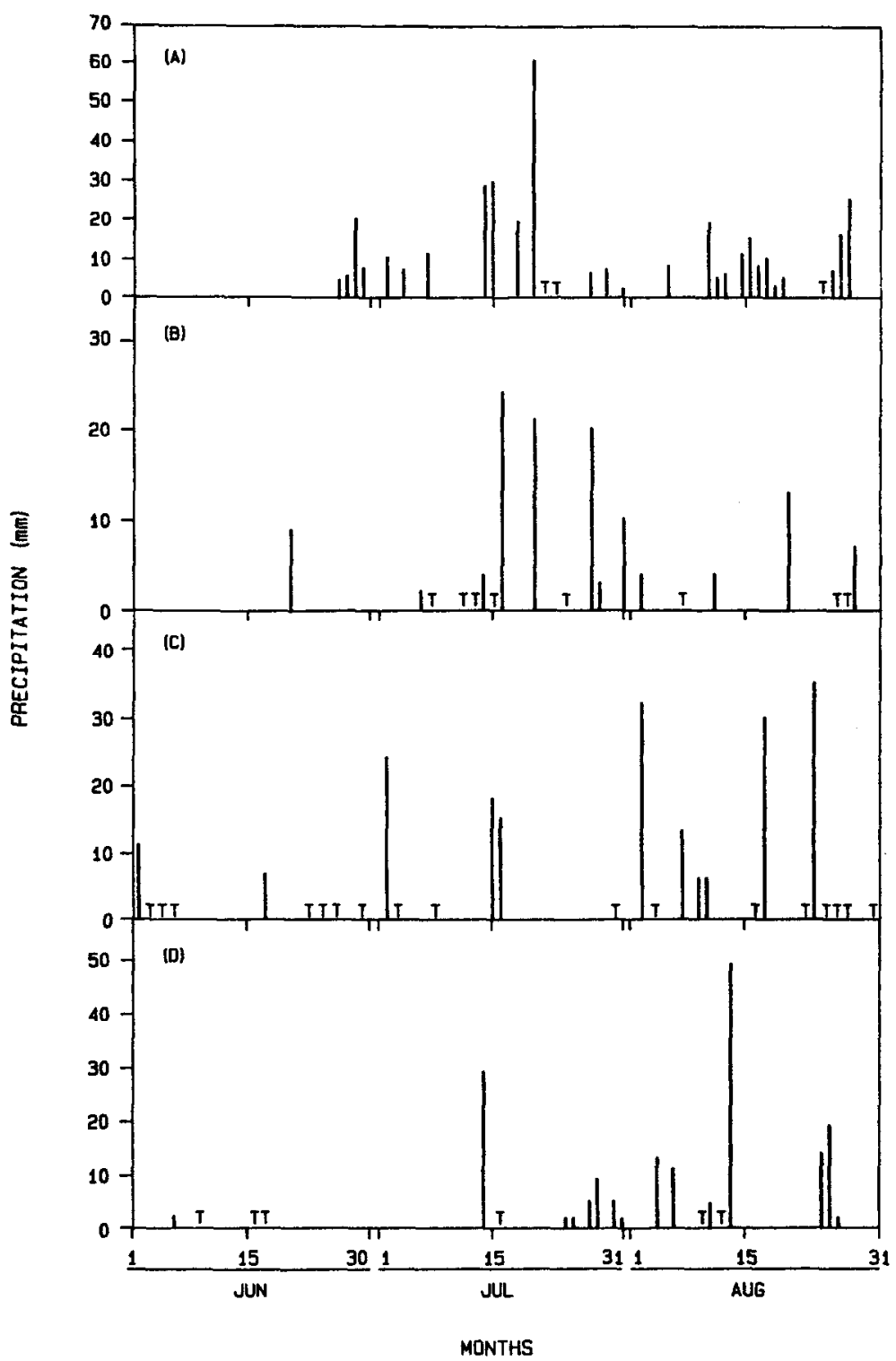

Fig. 3. Summer precipitation distribution and amounts in 1984 (A), 1985 (B), 1986 (C), and 1987 (D) at a Lehmann lovegrass site in southeastern Arizona. The letter $\mathbf{T}$ denotes a measurement of $2 \mathrm{~mm}$ or less.

produced no live biomass because surface soils dried in 2 to 4 days. In August 1987 temperatures cooled, rainfall amount and distribution increased (Fig. 3), and growing conditions in the final 14 days were equivalent to the final days of July 1984,1985 , and 1986. Our observations indicate that the 30-day growth delay reduced peak culm production by 30 to $45 \%$ and peak leaf production by 10 to $15 \%$.

In southeastern Arizona precipitation is bimodally distributed, and summer precipitation has the greatest affect on plant growth (Cully 1943). The coefficient of determination $\left(r^{2}\right)$ between accumulative summer precipitation and the summer growth of Lehmann lovegrass was $\mathbf{0 . 6}$ and similar to that reported for native perennial grasses (Cable 1975). Hence about two-thirds of the summer growth of Lehmann lovegrass can be accounted for by accumulating June to August precipitation. The $r^{2}$ value improves to 0.9 (Fig. 4) when 1 to $9 \mathrm{~mm}$ storms are excluded if they occur (1) before a large storm ( $\geq 20 \mathrm{~mm}$ ) in June and July, or (2) when daily temperatures consistently exceed $34^{\circ} \mathrm{C}$ for 5 or more days after a large storm.

\section{Recent-Dead Biomass}

Recent-dead biomass was different ( $P \leq 0.05$ ) among years at 5 summer sampling dates and similar at the remaining dates over the 3.5 years (Fig. 2-B). During typically mild winters (1983-84 and 1985-86), green culms from tillers produced in the previous February senesce slowly from top to bottom and all green disappears in June when temperatures peak (Cable 1975). Immediately following extreme cold temperatures in February 1985 and February 1987, we observed a rapid live to recent-dead transfer and expected a corresponding increase in recent-dead. Culms, however, regreened in 5 to 7 days and in spring there was no significant increase in recent-dead among years.

In the 3.5 years, recent-dead approached or equalled zero in late August (Figs. 2-A and 2-B). With each successive July and August storm, recent-dead weathered and transferred to old-dead (a yellow to gray color change). In summer, the recent- to old-dead transfer may occur in as few as $\mathbf{3 0}$ days or as many as $\mathbf{7 0}$ days but $75 \%$ of the recent-dead disappearance is explained by June to August precipitation (Fig. 5). In this instance $r^{2}$ values do not improve when small storms are excluded. 


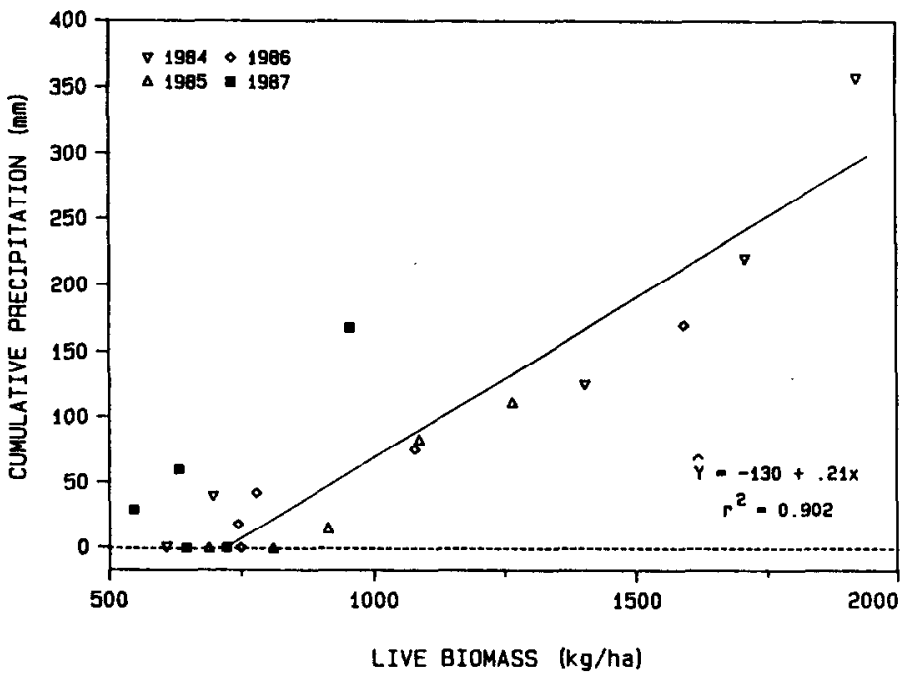

Fig. 4. Effect of cumulative summer (June-August) precipitation on live biomass production of Lehmann lovegrass in summers 1984-1987.

\section{Old-Dead Standing Biomass}

Old-dead standing biomass was different $(P \leq 0.05)$ at all sampling dates (Fig. 2-C); amounts were least in 1984, intermediate in 1985, and greatest in 1986 and 1987. Unusually low quantities in spring 1984 were related to livestock activity prior to fencing, and amounts remained low during the atypically wet summer of 1984 . During atypically wet summers, termites (Gnathamitermes perplexus) may totally harvest old-dead standing biomass in semidesert grassland communities, but when summer precipitation is average or below $(1985,1986$, and 1987) old-dead standing accumulates (Cox 1984).

Between December 1984 and February 1985, there were 7 separate occasions when snow depths ranged from 10 to $30 \mathrm{~cm}$. Snow weight pushed dead standing to the soil surface and $60 \%$ of the recent-and old-dead standing components disappeared in 90 days. Old-dead standing began to increase 1 year after fencing and continued to increase through 1987.

In each year, old-dead standing increased in spring and peaked in summer (Fig. 2-C) when daytime temperatures (Fig. 1-B) and wind velocities were highest (Cox 1984). Amounts declined in July when relative humidity was highest (unpublished data, USDAARS, Tucson, Ariz.), and peaked a second time in August when recent-dead approached or equalled zero (Fig. 2-B). Old-dead gradually increased or decreased between September and December, disappeared following snows in January, and accumulated following freezing temperatures in February.

\section{Litter}

Litter quantities were different $(P \leq 0.05)$ at all spring and early summer sampling dates and similar at the remaining dates over the 3.5 years (Fig. 2-D). Litter amounts in spring and early summer 1984 exceeded those in other years because old culms, dislodged by cattle prior to fencing, remained on the soil surface until July 1984. Litter generally peaked before the summer rains, gradually decreased during summer rains, increased in dry winters, and decreased in wet winters when snow accumulated to $30 \mathrm{~cm}$ depths (January 1985 and January 1987).

In Lehmann lovegrass communities, litter is a mobile component that can be redistributed by wind and water. Observations suggest that runoff moves culm and leaf fragments from beneath Lehmann lovegrass canopies, and fragments accumulate in open spaces between plants in summer and winter. Litter accumulations between plants slow runoff and surface soil $(0-15 \mathrm{~cm})$ moisture in

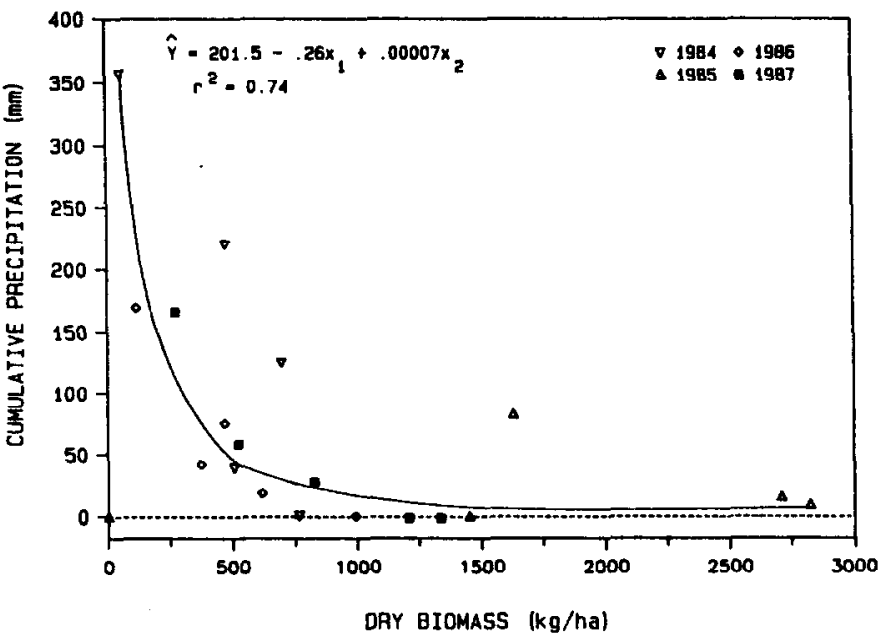

Fig. 5. Effect of cumulative summer (June-August) precipitation on the loss of recent-dead standing Lehmann lovegrass in summers 1984-1987.

untreated Lehmann lovegrass stands may be 15 to $20 \%$ greater than in stands where litter was removed (unpublished data, USDA-ARS, Tucson, Ariz.). In spring and fall, litter accumulations between plants disappear and plant fragments, redistributed by wind, accumulate beneath plant canopies. Litter may serve as a nitrogen $(\mathrm{N})$ reserve which becomes available to forbs in late winter and perennial grasses in summer (Cox 1985).

\section{Implications}

Cable and Martin (1975) reduced mesquite [Prosopis juliflora var. velutina (Woot.) Sarg.] densities on the Santa Rita Experimental Range and determined summer precipitation effects on native perennial grass production. Their study sites are near our study site and soil chemical and physical properties are equivalent among sites (Hendricks 1985). Summer precipitation amounts and distributions between 1957 and 1966 (Cable 1971) are generally equivalent to years between 1984 and 1987 . When summer precipitation is below, equal to, or above the long-term average, native perennial grass production averaged 270,430 , and $725 \mathrm{~kg} / \mathrm{ha}$, respectively, while under similar climatic and edaphic conditions, Lehmann lovegrass production averaged $960,1,430$, and 1,925 $\mathrm{kg} / \mathrm{ha}$. Our most important finding is that in dry summers, when green forage availablity limits livestock production, Lehmann lovegrass produces almost 4 times more forage than native grasses. These results may be influenced by livestock exclusion and variability in soil fertility, but there is no doubt that potential forage production on southeastern Arizona rangelands increased after the introduction of Lehmann lovegrass.

In pastures where Lehmann lovegrass occurs with native grasses, selective cattle grazing may favor the establishment and spread of Lehmann lovegrass. Under conventional year-long grazing, cattle prefer palatable native grasses during the summer growing season and lightly graze Lehmann lovegrass (Martin 1983). In contrast, cattle utilize Lehmann lovegrass in fall, winter, and spring because foliage remains green longer than native grasses (Cable and Bohning 1959). This seasonal pattern of animal selectivity reduces native grass vigor, because plants are repeatedly grazed during active growth.

Observations, however, suggest that multiple grazing events are limited by Lehmann lovegrass growth characteristics. If defoliated in winter, Lehmann lovegrass initiates spring growth 2-3 weeks before native grasses, and if defoliated in summer, the grass remains green longer into the fall (Cable 1971, 1976; Fourie and 
Roberts 1977; Ruyle et al. 1988) but regrowth may be unavailable to cattle. After defoliation, Lehmann lovegrass leaves originate in the crown rather than from recently defoliated tillers, and new leaves frequently elongate horizontally within the crown and beneath a coarse stubble of defoliated tillers. Leaves from Arizona cottontop [Digitaria californica (Benth.) Henr.], a preferred native grass, originate from grazed tillers or newly emerging crown tillers and regrowth is elevated above previously defoliated tillers (Cable 1971). Selective animal avoidance may be partially responsible for the spread of Lehmann lovegrass in Arizona (Galt et al. 1969) and southern Africa (Fourie and Roberts 1976).

Fencing should be used to separate pure Lehmann lovegrass stands from native grasslands invaded by Lehmann lovegrass because cattle selectively remove native grass dead standing crop before grazing Lehmann lovegrass green growth. We suggest grazing Lehmann lovegrass pastures when crude protein, phosphorus, and organic matter digestibility peak in spring and summer (Obo 1986). Land managers should rest native pastures in spring and summer, and moderately graze in fall and winter when grasses are inactive.

\section{Literature Cited}

Bryan, K. 1925. Date of channel trenching (arroyo cutting) in the arid southwest. Science 62:338-344.

Cable, D.R., and J.W. Bohning. 1959. Changes in grazing use and herbage moisture content of three exotic lovegrasses and some native grasses. J. Range Manage. 12:200-203.

Cable, D.R. 1971. Growth and development of Arizona cottontop [Trichachne californica (Benth.) Chase.] Bot. Gaz. 132:1 19-145.

Cable, D.R., and S.C. Martin. 1975. Vegetation responses to grazing, rainfall, site condition, and mesquite control on semidesert range. USDA-Forest Serv. Res. Pap. RM-149, Fort Collins, Colo.

Cable, D.R. 1975. Influence of precipitation on perennial grass production in the semidesert southwest. Ecology 56:981-986.

Cable, D.R. 1976. Twenty years of change in grass production following mesquite control and reseeding. J. Range Manage. 29:286-289.

Climatology of the United States (Arizona). 1982. Nat. Oceanic and Atmos. Admin. Ashville, N.C.

Cooke, R.U., and R.W. Reeves. 1976. Arroyos and environmental change in the American southwest. Clarendon Press, Oxford.
Cox, J.R. 1984. Shoot production and biomass transfer of big sacaton [Sporobolus wrightii]. J. Range Manage. 37:377-380.

Cox, J.R. 1985. Above-ground biomass and nitrogen quantities in a big sacaton [Sporobolus wrightii] grassland. J. Range Manage. 38:273-276.

Cox, J.R., and G.B. Ruyle. 1986. Influence of climatic and edaphic factors on the distribution of Eragrostis lehmanniana Nees in Arizona, USA. I. Grassl. S. Afr. 3:25-29.

Crider, F.J. 1945. Three introduced lovegrasses for soil conservation. USDA Circ. 730. U.S. Gov. Print. Off. Washington D.C.

Cully, M. 1943. Grass grows in summer or not at all. Amer. Hereford. J. 34:9-10.

Fourie, J.H., and B.R. Roberts. 1976. A comparative study of three veld types of the Northern Cape: Species evaluation and yield. Proc. Grassl. Soc. S. Afr. 11:79-85.

Fourie, J.H., and B.R. Roberts. 1977. Seasonal dry matter production and digestibility of Themeda triandra and Eragrostis lehmanniana. Agroplanta 9:124-133.

Galt, H.D., B. Theurer, J.H. Ehrenreich, W.H. Hale, and S.C. Martin. 1969. Botanical composition of diet of steers grazing on desert grassland range. J. Range Manage. 22:14-19.

Green, C.R., and S.C. Martin. 1967. An evaluation of precipitation, vegetation and related factors on the Santa Rita Experimental Range. Univ. Arizona, Inst. of Atmos. Phys. Tech. Rep. on Meteorology and Climatology of Arid Regions, No. 17.

Griffith, D. 1901. Range improvement in Arizona. USDA, Bureau of Plant Industry, Bull. 67. U.S. Gov. Print. Off., Washington, D.C.

Hendricks, D.M. 1985. Arizona soils. Univ. Arizona Press, Tucson.

Humphrey, R.R. 1958. The desert grassland. Bot. Rev. 24:193-253.

Martin, S.C. 1983. Responses of semi-arid grasses and shrubs to fall burning. J. Range Manage. 36:604-610.

Obo, P.G. 1986. Effects of prescribed burning on the nutritive quality of Lehmann lovegrass (Eragrostis lehmanniana). M.S. Thesis, Univ. Arizona, Tucson.

Ruyle, G.B., P.R. Ogden, and R.W. Rice. 1988. Defoliation patterns of cattle grazing Lehmann lovegrass (Eragrostis lehmanniana Nees). Appl. Agr. Res. 4:177-181.

Sellers, W.D., and R.H. Hill. 1974. Arizona climate (1931-1972). Univ. Arizona, Tucson.

Steel, R.G.D., and J.H. Torrie. 1960. Principles and procedures of statistics. McGraw Hill, New York.

Upson, A., and W.G. McGinnies. 1939. Range research contributes to progress in range management. Cattleman. 2:6-8.

Wagner, J.J. 1952. History of the cattle industry in southern Arizona 1540-1940. Univ. Arizona, Soc. Sci. Bull. 20. 